\title{
KNOWLEDGE PRODUCTION, LEARNING, AND (META)COGNITION IN INTERNATIONAL RELATIONS THEORY: A CASE STUDY IN BRAZIL
}

\author{
PRODUÇÃO DE CONHECIMENTO, APRENDIZAGEM E (META) \\ COGNIÇÃO EM TEORIA DAS RELAÇÕES INTERNACIONAIS: UM \\ ESTUDO DE CASO NO BRASIL
}

Fabiana Esteves Neves ${ }^{1}$

Ivi Vasconcelos Elias ${ }^{2}$

\begin{abstract}
This paper investigates the learning and the production of theoretical thinking in International Relations (IR) undergraduate courses in Brazil. We argue that students' inability to read and write academic texts is related to metacognitive issues and theoretical choices taken in academic settings. This hypothesis is grounded both in the context of Brazilian educational system, which emphasizes conceptualization rather than analytical thinking, and the predominance of traditional positivist approaches, which are unrelated to the context of developing countries like Brazil. The theoretical basis of this article comprehends principles from critical pedagogy and cognitive sciences, focusing on four metatextual language functions: report, summarize, analyze and theorize (NEVES, 2015). In order to describe students' production, a diagnostic questionnaire about a coursebook chapter was proposed to 35 students attending the course "IR Theory I". The answers for four of the questions show that lack of autonomous thinking in the discipline is reflected in students' understanding expressed through perfunctory writing. Consequently, the possibility of students becoming active subjects in both understanding and transformation of international politics is denied. In terms of reading and writing, metacognitive reflections must be included not only in language teaching, but also in theoretical courses, especially when dealing with academic texts.
\end{abstract}

Keywords: Language/Linguistics; (Meta)cognition; International Relations Theory; Developing Countries.

RESUMO: Este artigo investiga a aprendizagem e a produçăo de conhecimento teórico na graduaçăo em Relaçōes Internacionais (RI) no Brasil. Consideramos que as dificuldades do estudante para ler/escrever textos acadêmicos se relacionam a questóes metacognitivas e escolhas teóricas no âmbito acadêmico. Essa hipótese fundamenta-se tanto no contexto educacional brasileiro, que prioriza conceituaçóes,

Instituto Federal de Educaçâo, Ciência e Tecnologia, Campus Niterói/RJ. Doutora em Letras Vernáculas. Professora EBTT de Língua Portuguesa e Língua Inglesa. fabiana.neves@ifrj.edu.br.

2 IBMR; Iuperj-UCAM, Rio de Janeiro/RJ. Doutoranda em Relaçôes Internacionais - UERJ. Professora do curso de Relaçôes Internacionais. ivi.v.elias@gmail.com 
no lugar do raciocínio analítico, quanto na predominância de abordagens positivistas tradicionais, desconectadas da situaçáo de países em desenvolvimento como o Brasil. A fundamentaçâo teórica compreende princípios da pedagogia crítica e das ciências cognitivas, com foco em quatro açóes metatextuais com a escrita: reportar, sumarizar, analisar e teorizar (NEVES, 2015). Para descrever a produçăo dos estudantes, propôsse a 35 alunos da disciplina "Teoria das RI I" um roteiro de leitura diagnóstico sobre um capítulo de livro teórico. As respostas para quatro das questôes mostram que a falta de pensamento autônomo na disciplina se reflete na compreensáo dos alunos, expressa por meio da escrita perfunctória. Consequentemente, nega-se a possibilidade de se tornarem sujeitos ativos na compreensáo e transformaçăo da política internacional. Quanto à leitura/escrita, reflexóes sobre os aspectos metacognitivos do aprendizado precisam ser incluídas náo apenas no ensino da linguagem, mas também nas disciplinas teóricas, especialmente no trato com textos acadêmicos.

Palavras-chave: Linguagem/Linguística; (Meta)cogniçăo; Teoria das Relaçôes Internacionais; Países em desenvolvimento.

\section{INTRODUCTION}

One of the greatest problems faced by professors in Brazil is students' inability to read and write academic texts, especially when understanding the relations between arguments and their various levels of importance to the development of scientific theories. In International Relation (IR) programs, this situation is further aggravated by the character of the courses offered in the curriculum, mostly based on traditional theories - realism and liberalism. It is commonly assumed that these theories do not provide knowledge that can be directly related to the context of developing countries in which Brazilian students are inserted.

Teaching undergraduate IR courses in a private college at the city of Niterói, Rio de Janeiro, Brazil, showed that many students failed to express a greater understanding of academic texts studied in class when answering essay questions in exams. Therefore, it was necessary to detect and describe problems in the way students relate concepts in IR written theoretical materials with the phenomena discussed in those writings, especially when being tested in formal assignments. They usually do not pay special attention to the analyses made by academic authors, explanations that are actually the core of academic research. Thus, the central hypothesis of this study was that, even after reading theoretical writings, attending classes and studying on their own, students only cognitively perceive and consider conceptual statements as relevant.

This hypothesis is grounded on the context of Brazilian educational system, considering especially the undergraduate students' academic background. In primary and secondary levels, across the curriculum, more relevance is given to conceptualizing and classifying items rather than to applying concepts in problem solving tasks. This approach has been called "the banking model education" criticized by Paulo Freire (2011a). Despite the fact Brazilian educational laws have been reformulated in the past 20 years the use of this model can still be noticed in schools and universities, especially in the curricula of theoretical courses in IR programs. 
The traditional positivist theories - realism and liberalism - predominate in the development of the syllabus promoting an understanding of international politics that is centered on the repetition of the "cooperation and conflict" dynamics. The lack of attention given to critical theoretical approaches that emerged in the field after the Cold War period disfavor the learning of more critical conceptions about the theory role, as well as the elaboration of a more humanistic profile for International Relations. It is also argued that this traditional approach fails in stimulating students' analytical thinking skills, once it does not bring knowledge related to the insertion of Brazil as a peripheral and emergent country in the international system. Therefore, students are stimulated to repeat concepts in test answers and not to give attention to how those concepts can be used to analyze the dynamics and constitution of international politics.

Considering this scenario, this paper will be organized in six sections. After the introduction, the IR teaching context in Brazil will be detailed in section 2, in the light of a critical pedagogy view proposed by Freire (2011). In section 3, a cognitive analysis will be discussed in order to sustain the analysis of students' written production. Metacognitive and metalinguistic approach to teaching and learning (FLAVELL, 1979; GOMBERT, 1992) will be explained, as well as some key concepts about language functions (BRITTON et al., 1975; NEWELL, 2006; NEVES, 2015). In addition, four main functions for the reading and writing of academic texts (reporting, summarizing, analyzing and theorizing) will be presented in this section.

Following a brief methodology section (section 4), the results of a diagnostic questionnaire will be displayed, analyzed and discussed in section 5 . Finally, in section 6 , final remarks will be made in order to provide an overall view of both political and cognitive analysis.

\section{IR CONTEXT IN BRAZIL AND CRITICAL PEDAGOGY}

Theoretical discussion in Brazil remains focused in an American vision and its commitment to positivist methodologies. Thus, in Brazilian IR teaching, the mainstream point of view still predominates in knowledge production. Ironically, there is not an actual international theoretical reflection in the field. IR curriculum guidelines issued by the Brazilian Association of International Relations (ABRI) in 2013 also privilege the classical debate (ABRI, 2013).

This traditional approach also fails in stimulating analytical thinking in students. As it defines international politics as power politics, it does not bring knowledge that can be related to the issues that are part of the political agenda of a country such as Brazil, a country characterized in the international system as developing, emergent, peripheral and located in the global South. Maintenance of this emphasis in undergraduate curricula helps to perpetuate a specific view of IR as an area of studies apart from topics that are more related to the daily life of Brazilian undergraduates, such as poverty, development, environmental issues, and human rights. This conceptualization of IR can also be noticed in the recent spread of studies about Brazil as an emerging country, BRICS (Brazil, Russia, India, China, and South Africa), for example, which equate power acquisition to development over issues such as human rights and grass-roots demands (see HERZ, 2002). 
Although critical perspectives that appeared in the discipline after the end of the Cold War - i.e., constructivism, post-modernism, gender studies, among others - keep a closer dialogue with other fields of study in Humanities in a broader sense, they still occupy little curricula space in most universities in Brazil. These critical theories tend also to be seen as too hermetic and abstract by both students and professors.

Thus, it is noticed that theoretical teaching in International Relations departments in Brazil does not encourage a more critical analysis among students and, as a consequence, reaffirms the imaginary that international politics is the discourse about state actions based in power politics logic. This arrangement reinforces students' tendency to reproduce concepts in essay test answers without perceiving their application in analysis and constitution of specific dynamics in international politics. It favors the banking approach of IR as technical knowledge aimed at problem solution which reinforces power politics as theory and practice.

In Brazil, International Relations history is most commonly depicted as a succession of theoretical debates. This aspect is consonant with the traditional way the discipline defines itself, which maintains the predominance of an area of studies centered in American vision and compromised with positivist methodologies. According to Tickner (2011), IR continues to produce its theories about the world from the perspective of central states but at the same time claiming a universalism in their core assumptions about global politics dynamics. As a result, there is not a truly plural and international thinking in the discipline about international politics (TICKNER, 2011).

Thus, prevailing narrative in the history of International Relations as a field of study is described as a series of theoretical debates that dispute notions of right and wrong with a strong influence by positivist epistemology. Waever (1998) points out that this dominant narrative delimits the centers of power in the discipline, which include the most powerful countries as the realm of wealth and the legitimate production of knowledge, at the same time. The first debate brings the discussion between realism and liberalism and marks the ascendance of American power. The second one, between classical and behavioral methodologies, brings the assertion of a more scientific character in IR with the spread of notions, such as rational choice, statistics, and application of formal models (WAEVER, 1998).

In the same line of reasoning, Hoffman (1977) analyzes that the post-Second World War constituted a favorable environment for scientific tradition to blossom. The search for problem solving resolution in international politics was also a strong American feature. The scientific method would claim to achieve neutrality and impartiality in knowledge production privileging empirical studies and hypothesis testing. This supposed absence of values helped placing scientific method as a powerful authority speech that would serve as a parameter to evaluate other theories' credibility (HOFFMAN, 1977).

As a consequence of privileging causal analysis, there is a difficulty in acknowledging the importance and legitimacy of interpretative reasoning made by critical theories in IR. Having in mind that academic analysis usually inspires formulation of policies, this situation also contributes to a (re)production of political hegemonies in international politics.

The neutrality and universalism claimed by traditional theories demonstrate IR intentions to be a truly international discipline, i.e, relevant to all peoples and states. 
However, this is a symptom that hides Eurocentric and westfalian bias in the construction of an international historical mythology. In this sense, there is no recognition of historical legacies left by colonization and imperialist processes, for example. IR as a field of study is born in the early 20th century motivated by a concern to manage imperialism, i.e., searching for solutions to assure dominance at the global level. As such, IR is actually an "occidental science" (HALPERIN, 2006).

Willinsky (1998) observes that the search for knowledge of humanity within a global imperial context enabled the emergence and dissemination of race, nation and cultural ideas that were used to divide and educate the world. In this context, critical voices are still engaged in responding to occidental knowledge tradition what causes the colonized not having space to tell their own version of history.

Therefore, it is relevant to put into discussion the question raised by Tickner (2010): which knowledge is considered legitimate and which knowledge is ignored in IR? There are still enormous inequalities in material resources that determine where and by whom knowledge is produced. Hierarchies of power and the lack of disciplinary self-reflection combine to hinder the creation of a more inclusive IR. This inclusion must be considered both from geographical and methodological borders.

As a result of these inequalities there is the establishment of asymmetrical knowledge flows between North and South in the globe. It is noticed an intellectual dependency scenario in which concepts and categories derived from the South have limited application in other social and cultural contexts. Peripheral states have their condition of active subjects in knowledge production regarding international politics denied.

Hence, most part of knowledge production concerning global periphery comes from central areas. Periphery is usually represented through concepts evoking some kind of superiority and difference, i.e, underdevelopment, political authoritarianism and state failure. All these concepts emphasize lacking elements, so that periphery is not analyzed considering what it presents but mainly according to what is missing in their landscape (TICKNER, 2010).

Repetition and institutionalization of these concepts cause them to appear neutral, objective and static. Hegemony is acutely perceived in this process of generating static categories to interpret the world. In the end, these categories become the legitimate lenses through which one can analyze international politics (Doty, 1996).

Tickner (2010) notices that there is knowledge production in the periphery. Import of concepts usually occurs among a context with pre-existent knowledge causing hybridism to happen. In this sense, knowledge from the South is located borderline in relation to dominant knowledge, but not totally outside its frontiers. However, local peripheral knowledge does not find enough space to engage in dominant theoretical discussion in or outside universities. In Brazil, and in Latin America in general, it is possible to highlight some local contributions to the understanding of international politics, such as the dependency theory (SANTOS, 1998).

\section{Critical pedagogy}

Paulo Freire (2011a) advocates that the "oppressed" would be capable to overcome their impotence feeling and act on behalf of themselves to socially transform their 
existence. In his conception, education should have its basis in students' everyday life. Therefore, education would be a collaborative process in which social and political responsibilities are shared between students and teachers. Education is presented as a way to promote emancipation in two steps: the first one happens when human beings become conscious of their oppression and transform status quo through praxis. The second one ends in a process of permanent action seeking emancipation (FREIRE, 2011a).

According to Freire (2011b), literacy comprehends the individual capacity to perform a critical and political reading of the world aiming to transform it. In this sense, literacy is not only a method to learn how to read and write, but it is a more comprehensive concept that enables individuals to take a stand before political and ideological discourses of their time.

There is the recognition that, just like wealth, knowledge is unequally distributed in the world. In this sense, education would be the extension of political activity and its concrete implications in coexistence among people. This understanding is opposed to the notion that reality is a given fact, objective, passive, and independent of human action. As envisaged by Freire (2011b), education for freedom is a political act seeking to denounce hierarchical, authoritarian and exclusive systems in order to demand the adoption of a collective action towards the construction of a more inclusive and democratic social order.

Henceforth, the pedagogy of freedom aspires to lead students to reflect about their own historical experiences and social position. The ultimate goal is to enable them to question the present condition so that they can understand that reality is subject to change.

Individual relationship with reality generates a bond, called human conscience, which is expressed in language. According to Freire (2011a), conscience has three different levels of reality apprehension: primary, magical and critical. Primary conscience is resumed to survival issues and to biophysical imperatives. Magical conscience is present when the individual attributes to superior entities such as fate and luck the power to shape reality. Magic underestimates individual capacity to interpret reality and can be directly associated to Marx's concept of alienation. Critical conscience occurs when magical explanation is replaced by permanent reality analysis and praxis.

In this way, critical conscience intends to move beyond problems' surface promoting a deeper understanding of situations. This allows the emergence of questioning among students and makes possible for them to review their existential positions and contradictions. In Freire's view (2011a), critical conscience development is essential to strengthen the sources of democracy. The state, not only the school, should be responsible for encouraging critical conscience development.

To achieve critical conscience in the pedagogy of freedom it is necessary that the individuals learn with their own practice. In Freire's words:

To prevent adult literacy to become a pure mechanical process and merely a question of memorization, it is necessary to give them means of awareness (...), because, as an active method helps individuals to become aware of its own limitations, his condition of being a person and a subject he will acquire instruments that will allow him to make choices (...) Thus he will politicize himself (FREIRE, 2011a, p. 78) 
The pedagogy of freedom proposes a dialogic method opposed to traditional education considered a banking education. The banking character of education consists of an understanding of learning that encompasses basically deposit, transfer and transmission of knowledge. Students would come to school as clients to the bank seeking to withdraw their deposit of knowledge and "fill" their heads. This deposit includes knowledge previously selected and manufactured by educational institutions and teachers. Students are seen only as an empty vessel that should be filled with the richness of official knowledge approved by established powers (GAUTHIER; TARDIFF, 2010).

Therefore, banking education is strictly passive in nature and perpetuates hierarchy between students and teachers. Teachers are taken as legitimate knowledge holders and students, merely recipients. In this conception, teaching would consist of bringing to students knowledge that is not part of their daily life experiences. Banking knowledge is centered in narratives and cannot be related to students' subjectivity based in their social and political context. Students, in their passive and submissive role, repeat concepts whose contents are detached from their reality. As a result, the banking approach generates alienation and prevents the emergence of critical conscience (FREIRE, 2011a).

Awareness in pedagogy of freedom requires a rupture with established myths to allow the individual to achieve other levels of conscience enabling individuals to be conscious of living in a condition of oppression in a world where only a few people have power. Education as a freedom practice is at the same time an act of knowledge and a critical approach to reality (FREIRE, 2011c).

It is important to notice that the dialogue proposed by the dialogic method is only possible when the student is recognized as an active agent in knowledge production. Students and teachers could then establish a relationship based in cooperation and interchangeability of roles. Only if this condition is fulfilled, the students will be able to act as subjects in knowledge production.

In short, to Paulo Freire, pedagogical methods are not instruments independent of context, values and intentions. There is not an ideal pedagogy, every approach to education must engage with real problems faced by students instead of being a set of tools imported from somewhere else. Obsession with methodologies tends to push away philosophical and political debates and privileges operational and instrumental forms of knowledge.

\section{METACOGNITION, METALANGUAGE AND LANGUAGE FUNCTIONS}

Paulo Freire's (2011a) mentioned awareness suggests a social connotation, that is, the perception, by learners, of their role in the social process of education and in their own process of becoming conscious. In terms of a metacognitive approach, the teaching and learning of reading and writing that focus on students' autonomy must include the observation and evaluation of metacognitive strategies they adopt to deal with their own learning. Flavell (1979) defines metacognition as the knowledge and thoughts of individuals about their own knowledge and thoughts. In his article "Metacognition and cognitive monitoring", Flavell (1979, p. 906) asks a central 
question: "what adultlike knowledge and behavior might constitute the developmental target here, toward which the child gradually progresses?". In other words, what matters is considering that people do not only think automatically about their own cognition - as if this thinking consisted only of natural strategies of human cognition - but also that this ability can be consciously developed, and more, targeted to a better performance in intellectual work.

Since the main target of this research is the extensive work with text-reading and writing - the metacognitive aspects must be detailed, in order to attentively treat the actions and strategies that refer to students' relations with language. These specific metacognitive actions are comprehended in the study of the metalinguistic development, according to Gombert (1992). First, it is necessary to clarify the meaning and the use of "metalinguistic" in this context: in the language sciences, "metalanguage" and "metalinguistic" feature the language about language, according to what can be learned, since early years in Brazilian schools, with language functions proposed by Roman Jakobson (1975). Therefore, in this sense, metalanguage is usually related to taxonomy and a terminology of linguistic elements. However, in psycholinguistics, metalanguage and metalinguistic development name a field in metacognition that comprises: "(1) activities of reflection on language and its use; (2) subjects' ability intentionally to monitor and plan their own methods of linguistic processing (in both comprehension and production)" (GOMBERT, 1992, p. 13). Included in this reflection are the different aspects of language: phonologic, syntactic, semantic, pragmatic, textual. In this research, the aspect focused will be the knowledge, reflections and abilities referred to the text: the metatextual development.

Concerning the monitoring of textual structure, Gombert (1992) mentions, among other issues, researches that focus on the way children and adults monitor the general organization of the text, the perception of main ideas and the hierarchy of topic organization in different text types. Concerning the structure of academic text, the present research considers essential the perception of specific language/writing functions, that will be now detailed.

In the book The Development of Writing Abilities (11-18) (1975), James Britton et al. describe their research on the development of writing skills among 11 to 18 yearold students in the UK. This research was part of a three-year development project called "Writing Across the Curriculum", which was approved and established by the federal Schools Council. The project main objective was to promote written production in various school subjects, not only English.

The authors' first point is related to "a naïve global sense of the ability to write" (BRITTON et al., 1975, p. 1), which considers that this ability would be able to make students produce any kind of written material. Learning to write, then, would consist of mastering one single technique, which would be useful in all activities and curricular courses. In opposition to this conception, the authors propose a more specific approach, containing "satisfactory means of classifying writings according to the nature of the task and the nature of the demands made upon the writer" (BRITTON et al., 1975, p. 3). The main focuses are the functions of writing and the actions that must be taken to write accordingly to these functions. This approach aims at investigating the process of writing and its relation with students' development throughout their school life. 
According to Britton et al. (1975), the four rhetorical categories traditionally taught as writing strategies - narration, description, exposition, and argument - present two problems, which, in our research, are closely related to a "banking" model of education. The first problem refers to the fact that these categories are considered natural, that is, the only possible way of organizing written language. Therefore, students' role would be restricted to learning their characteristics and putting them into practice (BRITTON et al., 1975, p. 3). The second problem concerns a disregard of the mental processes applied to actual writing, once the main interest is in "how people should write, rather than with how they do" (BRITTON et al., 1975, p. 4). In the authors' words: "Suffice it to say here that such central concerns as the effect on the writer of what he writes, the needs he is satisfying, his actual procedures - these are obscured rather than illuminated by the distinctions embodied in the rhetorical categories" (BRITTON et al., 1975, p.5).

As in a "banking" model of education, the teaching of the four rhetorical categories, while demanding the reproduction of a few textual features, does not take into account the specific characteristics of the communicative contexts, nor the students' purposes in communicating and their cognitive efforts to do so. Therefore, the approach proposed by Britton et al. (1975, p. 6) adequately suits the main objectives of our research, due to its attention to the "development of writing in its relation to the development of thinking", which is the reason why they "focus upon the processes involved in writing".

In order to achieve their goals, Britton et al. (1975) analyzed 2122 texts produced by students in various school subjects, in the 1st, 3rd, 5th and 7th grades (from 11 to 18 years old). The authors point out that there are differences between tasks set by the teachers and the piece of writing produced: some of these differences are related to the specificities of each course; others, to the teachers' expectations, or to their relationships with the students. However, the main difference refers to "the degree of involvement in the writing task": "when, and if, he [the student] makes it his own it would appear not to differ from a self-imposed task, that is writing that is voluntarily undertaken" (p.7). The authors, then, distinguish writings in "involved" and "perfunctory": "When involved, the writer made the task his own and began to write to satisfy himself as well as his teacher; in perfunctory writing he seemed to satisfy only the minimum demands of the task" (p. 7-8). Although research subjects were children and teenagers, it seems possible to apply the distinction mentioned also to adult undergraduate students, in consonance with the "banking" model of education, to which, therefore, perfunctory writing would apply, as a product or amount yielded to be returned to the teacher.

Another problem highlighted is the lack of involvement with language called "impersonal", the most common both at school and at university: as the authors describe, some texts written by students reveal that "the writer seemed not to be in control of his writing but to be controlled by it", as if "the topic had the writer by the throat" (BRITTON et al, 1975, p.8). Mainly at this point a connection between language functions and a metacognitive/metalinguistic approach of reading and writing can be perceived. The main question is: how conscious of their own metacognitive and metalinguistic strategies are students while writing? This theoretical approach to writing and to students' perception about their own written texts does not constitute the authors' research, but clues to such concepts can be potentially detected. While attempting to define 
communicative categories that could comprehend all areas, based on similarities and differences related to functions, public and context (and not to the specific syllabus content), the researchers wanted to "trace the stages at which school students acquire the ability to modify their writing to meet the demands of different situations and thereby move from one kind of writing to the other" (p.9).

Based in Britton et al.'s (1975) function framework, Newell (2006) proposes a four-level categorization, which appears to be more adequate to academic writing, because it comprehends cognitive processes that go from the less autonomous to the most autonomous: report, summarize, analyze, theorize. Definitions to each function are displayed below. ${ }^{3}$ The following model sets the bases for the reading questionnaire, which is presented in details, in the next section.

Report: describe and/or narrate facts and phenomena, selecting features that are most relevant to prove arguments; quote arguments from authority, concepts or theories proposed by other authors. Using this strategy, the author includes external data and assertions that are very important to bring credibility to arguments.

Summarize: show the reader the main topics that will be or that have been exposed in the text. This can be done:

- explicitly, with words referring to topics that will be or have been presented in the text (such as "objective", "concepts", "principles", among many others);

- implicitly, with words that refer to the topic presented and constitute its semantic field.

Analyze: relate phenomena (facts, situations) and propositions (ideas, concepts), establishing conceptual and semantic relations between them. Through the actions related to this function, the author takes some distance from the facts and get to conclusions - that is, the author yields new ideas and statements.

Theorize: propose concepts, make generalizations about the topic, in order to define and establish a more adequate manner of dealing with the topic, according to the author. It is usually the most important language function in academic texts.

Framework proposed in one of the authors' PhD dissertation (NEVES, 2015).

\section{METHODOLOGY: READING QUESTIONNAIRE}

The diagnostic questionnaire that follows is based on the 1st chapter ("A realist theory of international politics") of Hans Morgenthau's founding book, Politics among nations (2005), in Portuguese. The "reading guide", also in Portuguese, contains 13 questions focused on the four language functions described above. Second year students attending the course "IR Theory I" were required to study this text. Before the class discussion about the chapter, students were given two hours to answer the questionnaires in class. 35 students, in morning and evening classes, answered the whole reading guide in their mother tongue, Portuguese.

3 These functions refer to the framework proposed in one of the authors' PhD dissertation (NEVES, 2015). 


\section{Reading guide - Politics among nations (Hans Morgenthau), chapter 1: "A Realist Theory of International Politics".}

The following questions do not focus on content of the text; their main objective is to observe the structure of academic text, the way language form/arrangement expresses different meanings. Understanding this structure will help you read and understand the content not only of this chapter, but also of other theoretical chapters.

Since your answers must focus on language, sometimes they may consist uniquely of a copy or a paraphrase of parts of the chapter.

Notice that this reading guide has two stages: some questions must be answered before reading the text, and some must be answered while reading the text. Follow the instructions carefully, in order to better profit from the activity. Make an effort to write clear answers.

Pre-reading activities: answer to these questions before reading the chapter.

1- Notice the chapter title: "A Realist Theory of International Politics". What is your understanding of "a theory"? And what is your understanding of the "realist" character applied to the theory?

2- Taking into account your answer to question 1, list the topics you expect to find in the chapter, including words and expressions which will probably be used throughout the text.

3- Based on the previous questions, we can summarize an important principle concerned to text structure: the relevance rate of a topic in a text can be measured by the frequency in which specific words and related expressions are used. Taking into account your answers to questions 1 and 2, which words might appear more frequently in the text, in your point of view?

4- Re-read your answers to questions 1 to 3 and think: what kind of information about the "Realist theory" can be found in the chapter, in your point of view?

\section{While reading and answering the following questions, keep in mind the answers you wrote for the pre-reading questions; read them back if necessary or if recommended below.}

During reading process: answer to the following questions while reading the chapter. Notice the references to pages and paragraphs, because reading will not follow text order.

5- Read the three examples presented on pages 23 to 26. In your point of view, why does the author choose these situations as examples? Moreover, can you identify clues in the chapter (words, expressions, sentences) that explain why the author decides to give examples on this part of the chapter?

6- Read the chapter introduction, that is, paragraphs 1 to 4 (pages 3 and 4). Re-read your answer to question 4 and answer: do you find, in the introduction, information you expected? If you found it, which one was it? If not, what kind of information is there in the introduction? In both cases: considering the chapter title, determine what information given in the introduction refers to: 


\section{A Realist Theory of International Politics}

\begin{tabular}{l|r}
\hline \multicolumn{2}{c}{ Information referring to: } \\
\hline Realist Theory & Internacional Politics \\
\hline
\end{tabular}

7- In paragraphs 2 and 3 of the introduction (pages 3 and 4), explaining in detail a theory of international politics), the author highlights the contest between "two schools that differ fundamentally in their conceptions of the nature of man, society, and politics" (paragraph 2). Sort out all information given about these three aspects, in two columns: one referring to the first school and the other referring to the second one (write, in a table like the following, words, expressions and sentences you find).

\begin{tabular}{c|c|c}
\cline { 2 - 3 } & First school & Second school \\
\hline Nature of man & & \\
\hline Nature of society & & \\
\hline Nature of politics & & \\
\hline
\end{tabular}

8- Summarize the chapter introduction extracting the following topics:

- The main purpose of the book;

- The main purpose of the chapter.

In order to achieve the proposed objective, the author presents the six principles of realism. List them, using your own sentences.

9- Which differences do you observe in the language used in the examples (go back to question 5) and in the presentation of the two schools (go back to question 7)?

10-Return to questions 8 and 9. In your point of view, is there any explicit connection, in the text, between the six principles presented by Morgenthau and the examples given? Explain your answer and give examples to justify it, quoting passages of the text.

11- The chapter introduction, after defining the main purpose of the book, presents an argumentation about "the test by which such a theory should be judged" (paragraph 1, page 3). When analyzing this paragraph, what is the author's purpose in presenting this argumentation, in your point of view? Is this topic mentioned again throughout the chapter? Explain your answer.

12- Paragraphs 2 and 3 (pages 3 e 4) discuss the "contest between two schools" (re-read your answer to question 7). While analyzing these two paragraphs, what is the author's purpose in focusing on this contest, in your point of view? And why does he choose to mention it at the beginning of the chapter?

13-At the end of paragraph 1, Morgenthau asks: "Is the theory consistent with the facts and within itself?" In your point of view, does he give an answer to this question throughout the chapter? Explain your answer using information from the text. 


\section{DATA DISCUSSION}

Before analyzing students' answers, some explanation must be given about the questions. As exposed in the questionnaire introduction (section 4 above), the activity was divided in two parts. The first four questions were pre-reading questions that were supposed to be answered before the reading of the text, in order to prepare students and activate previous knowledge. The other nine questions were required to be answered while reading the text. Questions 5 to 8 intended to detect students' perception about the reporting and summarizing of information in specific parts of the chapter, especially at the introduction and the examples given in the text. Question 9 expected the comparison, by students, of the language used while reporting and summarizing; comparing is an important cognitive process which highlights relevant characteristics in observed material. Question 10 focused on the connection between reporting (the examples) and theorizing (the six principles). Question 11 had the purpose of calling attention to the way an analytical path - the function of analyzing - has been established since the beginning of the chapter. Question 12 also aimed at the function of analyzing, through the perception of different weight given to each argument in the text. Finally, question 13 focused on the functions of analyzing and theorizing.

Four questions were chosen to be analyzed in this article: question 1, because it deals with previous knowledge - therefore, it can reveal some of students' conceptions about theory study itself and about the chapter topic; questions 11, 12 and 13 , because they presuppose an understanding of reporting and summarizing, since their main target are the functions of analyzing and theorizing. This choice allowed the observation of students' perception about the four functions. Before the presentation of data in each question answered, the expected response is explained.

\section{Question 1}

In question 1, it was expected that students would present a point of view about theory and realism which privileged, in the first topic, the analytical aspect of theoretical approaches and its discursive character, and, in the second topic, the same aspect specified by a realistic point of view, with its correspondent keywords. A panorama of quantified answers is presented in two tables below:

Table 1: answers to question $1-1^{\text {st }}$ topic

\begin{tabular}{c|c|}
\hline \multicolumn{2}{c}{ Question 1- 1 $^{\text {st }}$ topic: the understanding of theory } \\
\hline Answer types & Number of answers / percentage \\
\hline I- Explanation/study & $14-40 \%$ \\
\hline II- Tool/instrument & $7-20 \%$ \\
\hline III- Simplification of research subject & $6-17,1 \%$ \\
\hline IV- Dichotomy theory X practice & $4-11,4 \%$ \\
\hline V- Point of view about the world & $2-5,7 \%$ \\
\hline VI- Mixture of the perceptions above & $1-2,8 \%$ \\
\hline
\end{tabular}


Most answers considered theory as a way of explaining and studying reality (type I). 7 students (type II) answered that theory is a tool or instrument for problem solution and observation of reality. In both cases, it can be noticed a conception of reality as if it was stagnant, to be perceived and dealt with by theory. This aspect is directly related to the static and neutral appearance of concepts made by traditional theories in IR. As knowledge in the field is mainly imported from central areas, students tend to consider natural the notion of theory as an instrument that describes and not constitutes reality.

A more academic perspective can be noticed in types III and IV, in which the possibility of presenting a point of view about reality is taken into account. However, only type $\mathrm{V}$ - answers given by only two students - reveals a more analytical approach.

Table2: Answers to question $1-2^{\text {nd }}$ topic

\begin{tabular}{c|c}
\hline \multicolumn{2}{c}{ Question 1-2 ${ }^{\text {nd }}$ topic: the understanding of realism } \\
\hline Answer types & Number of answers / percentage \\
\hline I- An analysis of / based on reality & $11-31,4 \%$ \\
\hline II- A point of view based on Realistic principles & $9-25,7 \%$ \\
\hline III- Reality / the truth & $7-20 \%$ \\
\hline IV- Practice & $3-8,6 \%$ \\
\hline V- Unclear answers & $3-8,6 \%$ \\
\hline VI- Other answers & $2-5,7 \%$ \\
\hline
\end{tabular}

The analytical approach that was not so common in the first topic appears more frequently in the second topic of the question: the perception of "analysis" was present in approximately 31\% of the answers. Although these answers presented keywords related to realism, sentences seemed to be mere reports of phrases studied before, as some of them looked very much alike. In group II, the same tendency could be noticed; in spite of being closer to what was expected, some answers were vague, because they did not explain what realism consisted of.

Group III showed an inadequate perception of realism, which associated theory directly to "what is real or true". Some answers looked much alike the ones in group I, but the difference was that, in group III, there were no words to indicate that theory is a discursive framework: students reveal they read the words "realism", "realistic" in a literal way, as if they were a report of what was being observed.

Since this was a pre-reading question, its main objective was detecting the basis in which students conceptions about IR theory were founded; it was not our intention to describe their perception of the four communicative functions. This is being developed in the following questions.

\subsection{Question 11}

It was expected that students perceived the proposal of both an empirical and a pragmatic test of the theory, which determined an argumentative path that conducted the analysis throughout the chapter. The main focus of the question was, therefore, the function of analyzing. Students should also be able to notice this path in passages in other parts of the text. 
Table 3: answers to question 11

\begin{tabular}{c|c}
\hline \multicolumn{2}{c}{ Question 11 } \\
\hline Answer types & Number of answers / percentage \\
\hline I- Paraphrase of the original text & $13-37,1 \%$ \\
\hline II- Theory as an argumentative construction & $8-22,8 \%$ \\
\hline III- Vague or unclear answers & $8-22,8 \%$ \\
\hline IV- Theory as the truth & $6-17,1 \%$ \\
\hline
\end{tabular}

In quantifying the answers, it was not possible to report all the types literally because some tendencies were more evident than specific contents. The main example of it is type I: although students gave different answers to the question, it was evident that they paraphrased parts of the chapter. It may be inferred that, first of all, there was not adequate understanding of the question; secondly, there was no perception of the analytical purpose of the author's statement. Differently, in group II, students showed they perceived this analytical tendency. However, the same number of students (group III) gave answers that could not be understood; some of them revealed the misunderstanding of the question, others had inadequate linguistic expression. Finally, in group IV, although there were different answer patterns, a common basis was noticed: in order to explain the author's argumentation, students tended to consider realism as a true perception of reality, or the best theory.

In a metalinguistic perspective, in groups I and IV (almost 50\% of the answers), students revealed they did not distinguish between report/summarize and analyze, maybe because they were not aware of their own metacognitive actions while reading the text - that is, they may have considered all topics in the chapter as information to be highlighted and memorized, not to be interpreted as argumentative strategies.

\section{Question 12}

In answers for question 12, it was expected that students noticed that, when focusing the contest between two schools, the author aimed at opposing two theoretical approaches in order to highlight one of them and argue against the other one. This is a typical action of the analyze function, which is one of the most important in theoretical texts.

Table 4: answers to question 12

\begin{tabular}{c|c}
\hline \multicolumn{2}{c}{ Question 12 } \\
\hline $\begin{array}{c}\text { Answer types } \\
\text { I- Focus on difference between schools, but do not notice } \\
\text { there is a choice for one of them }\end{array}$ & Number of answers / percentage \\
\hline $\begin{array}{c}\text { II- Focus on difference between schools and highlight there } \\
\text { is a choice for one of them }\end{array}$ & $18-51,4 \%$ \\
\hline III- Unclear answers & $5-14,3 \%$ \\
\hline
\end{tabular}


The table shows that this opposition was detected, but its purpose was not - in fact, it means the analyze function was not perceived. Again, it can be inferred that information reported and summarized was adequately detected - the difference between schools - what confirmed the tendency to consider learning as memorization of data and concepts. Moreover, the way language expresses meaning and the reasons for doing so, in a theoretical chapter, were neglected. This cognitive behavior may consist of a sort of "heritage" from a way of thinking that is characteristic of school banking education model.

\section{Question 13}

The expectation for the answers to the last question comprehended the perception of the argumentative path developed throughout the chapter: students should have observed the empirical and pragmatic approach in applying the principles of realism, which was noticeable in the way the author analyzed the examples, i.e., the specific elements he took into account and the manner through which he explained them. Therefore, Morgenthau argued that to prove "the theoretical conception of realism is consistent with the facts and within itself", and that the other school presented (liberalism) was not. In terms of communicative functions, the analyzing function was applied to allow a conclusion which was expressed by means of the theorizing function of language.

Table 5: answers to question 13

\begin{tabular}{c|c}
\hline \multicolumn{2}{c}{ Question 13 } \\
\hline Answer types & Number of answers / percentage \\
\hline I- Vague answers & $12-34,3,8 \%$ \\
\hline II- Incoherent answers & $10=28,6 \%$ \\
\hline III- Answers that seem to detect the author's actions, but not clearly & $7=20 \%$ \\
\hline IV- Coherent / adequate answers & $5-14,3 \%$ \\
\hline
\end{tabular}

Once the answers presented different contents, it is necessary to explain why they have been classified as "vague", "incoherent" or "adequate". Most answers (group I) did not correspond to what was asked: some quoted aleatory passages of the chapter, while others evaluated the theory in itself, its validity or truth, not the author's communicative actions.

A great number of answers (group II) either stated that the author did not answer his own question throughout the text or quoted passages that were not appropriate as an adequate response. A smaller group (III), in spite of perceiving the question had been answered, was not able to explain it clearly, for not mentioning the empirical and pragmatic character of realism. Finally, group IV revealed a very small percentage of students who understood the author's intention.

Considering adequacy/inadequacy of answers, it is relevant to highlight the great percentage of students (almost 65\%, in groups I and II) that were not able to have a bird-eye view on the chapter, that is, students that did not go beyond the perception of parts of the text and, therefore, could not follow its argumentative flow, which would lead them to detect an analytical communicative action. 


\section{FINAL REMARKS}

As a conclusion, it is possible to relate the following aspects in this case study: the dominance of traditional theories in IR Brazilian curricula; the absence of autonomous thinking, especially the production of knowledge from the global South; and the "banking cognition" of undergraduate IR students.

Lack of autonomous thinking in the discipline is reflected in students' understanding expressed through perfunctory writing. Their answers privileged report and summarize language functions, what is consonant with the banking education observed by Paulo Freire (2011). This model reinforces hierarchies of power in IR knowledge production and maintains the appearance of neutrality in interpreting international politics as cooperation and conflict. In this sense, theoretical knowledge is seen by students as the description of a reality and it is valued as an instrument capable of solving problems.

As a result, the possibility of students becoming active subjects in both understanding and transformation of international politics is denied. As shown in this case study, students are stimulated to import theoretical concepts from traditional positivist and American theories, what makes difficult for them to learn from their own practice. An absence of dialogue between students and professors, i.e, between students and political and social context, is also revealed.

Although this research encompassed a single case study, the curricular predominance of traditional theories in most Brazilian undergraduate courses in International Relations turns possible to infer that there is a lack of space to develop critical conscience in Paulo Freire's sense. Therefore only the maintenance of magical explanations about power politics recurrence is constantly reinforced.

In terms of reading and writing, metacognitive and metalingustic reflections must be included not only in the teaching of language, but also in theoretical courses, especially when dealing with academic texts. Students must be taught how to read and write in an academic environment, and this involves changes in professors' practices, evaluation tasks and, eventually, in syllabi and curricula.

For an emergence of autonomy and critical conscience to occur it is essential to think of knowledge production and learning dynamics. It is essential to reflect about the way education, in its banking version, perpetuates traditional ways of thinking. It is not possible to raise an autonomous subject with an autonomous language without an autonomous education. And without an autonomous education it is not possible to create an autonomous thinking in IR. 


\section{REFERENCES}

ASSOCIAÇĀO BRASILEIRA DE RELAÇŌES INTERNACIONAIS. Minuta das Diretrizes Curriculares Nacionais. ABRI. <http://www.abri.org.br/informativo/view?TIPO=13\&ID_ INFORMATIVO=139>. Acessed on March 22nd, 2014.

BRITTON, J. et al. The Development of Writing Abilities. Hampshire: MacMillan, 1975.

DOTY, R.-L. Imperial encounters: the politics of representation in North-South relations. Minneapolis: University of Minnesota Press, 1996.

FLAVELL, J. H. Metacognition and Cognitive monitoring. AmericanPsychologist.v.1, n. 10, pp. 906-11, 1979.

FREIRE, P..Educaçáo como prática da liberdade. 50. ed. Rio de Janeiro: Paz e Terra, 2011c.

Educaçăo e mudança. 50. ed. Rio de Janeiro: Paz e Terra, 2011b.

Pedagogia do Oprimido. 50. ed. Rio de Janeiro: Paz e Terra, 2011 a.

GOMBERT, J.E. Metalinguistic Development. Chicago: University of Chicago Press, 1992.

HALPERIN, S. International Relations Theory and the Hegemony of Western Conceptions of Modernity. In: JONES, G. Decolonizing International Relations. Laham, Maryland: Rowman \& Littlefield, 2006.

HERZ, M. O crescimento da área de Relaçōes Internacionais no Brasil. Contexto Internacional, v. 24, n.1, pp. 7-40, 2002.

HOFFMAN, S. An American Social Science: International Relations. Daedalus, v.106, n. 3, pp. 41-60, 1977.

MORGENTHAU, H. A política entre as naçōes. Brasília: Ed. UnB, 2003.

Politics among nations. New York: MacGraw-Hill, 2005.

NEWELL, G. Writing to learn: how alternative theories of school writing account for student performance. In: MacARTHUR, C. A.; GRAHAM, S.; FITZGERALD, J. Handbook of writing research. New York: Guilford, 2006.

NEVES, F. E. Letramento linguístico acadêmico de estudantes universitárias/os: gerenciamento metalinguístico na leitura e na escrita. 2015. $324 \mathrm{f}$. Tese (Doutorado em Letras Vernáculas) -Doutorado em Letras: Faculdade de Letras, Universidade Federal do Rio de Janeiro, Rio de Janeiro, 2015.

SANTOS, T. dos. Por uma bibliografia sobre dependência. Estudos Avançados, v.12, n. 33, pp. 137-146, 1998.

TICKNER, A. Relaciones de conocimiento centro-periferia: hegemonía, contribuiciones locales e hibridización. In:RESTREPO, Gabriel.Construyendo lo global: aportes al debate de relaciones internacionales.Barranquila, Colombia: Editorial Universidad Del Norte, 2010.

Dealing with difference: problems and possibilities for dialogue in International Relations. Millennium: Journal of International Studies, v. 39, n. 3, pp. 607-618, 2011. 
WAEVER, O. The Sociology of a Not So International Discipline: American and European Developments in International Relations. International Organization, v. 52, pp. 687-727, 1998.

WILLINSKY, J. Learning to Divide the World: Education at Empire's End.Minneapolis: University of Minnesota Press, 1998. 